\title{
Review \\ Utilization of the Hollies (Ilex L. spp.): A Review
}

\author{
Xin Yao ${ }^{1,2, *(0)}$, Fan Zhang ${ }^{3}$ and Richard T. Corlett ${ }^{1,2}$ (D) \\ 1 Center for Integrative Conservation, Xishuangbanna Tropical Botanical Garden, Chinese Academy of Sciences, \\ Mengla 666303, China; corlett@xtbg.org.cn \\ 2 Center of Conservation Biology, Core Botanical Gardens, Chinese Academy of Sciences, Mengla 666303, China \\ 3 Jiangsu Key Laboratory for the Research and Utilization of Plant Resources, Institute of Botany, \\ Jiangsu Province and Chinese Academy of Sciences, Nanjing 210014, China; mumizhongfeng@126.com \\ * Correspondence: yaoxin@xtbg.org.cn
}

check for

updates

Citation: Yao, X.; Zhang, F.; Corlett, R.T. Utilization of the Hollies (Ilex L. spp.): A Review. Forests 2022, 13, 94. https://doi.org/10.3390/f13010094

Received: 22 November 2021

Accepted: 6 January 2022

Published: 10 January 2022

Publisher's Note: MDPI stays neutral with regard to jurisdictional claims in published maps and institutional affiliations.

Copyright: () 2022 by the authors. Licensee MDPI, Basel, Switzerland. This article is an open access article distributed under the terms and conditions of the Creative Commons Attribution (CC BY) license (https:// creativecommons.org/licenses/by/ $4.0 /)$.

\begin{abstract}
The hollies (Ilex L., Aquifoliaceae) form a large (>669 spp.) genus of forest trees and shrubs, which is almost cosmopolitan in mesic environments but most diverse in subtropical China and montane South America. Throughout the range of the genus, Ilex species have been utilized as beverages, medicines, ornamentals, honey plants, timber, and for various other minor uses. Recent studies on the genomics, evolution, and biogeography of Ilex now make it possible to take a systematic approach to understanding and expanding the economic importance of the genus, but information on existing uses is scattered among numerous published and unpublished sources. We therefore review the existing literature on utilization of Ilex species, supplementing this with information from the grey literature and product websites. We show that, despite the number and diversity of known uses, most Ilex species are not known to be utilized at present, suggesting considerable unrealized potential. We highlight gaps in our knowledge and opportunities for expanded usage. Finally, we discuss how the availability of a new phylogeny and whole genome can assist screening of additional wild species for economic potential and facilitate breeding programs for species already under cultivation.
\end{abstract}

Keywords: guayusa; horticulture; kudingcha; traditional medicine; yaupon; yerba maté

\section{Introduction}

Hollies are shrubs and trees in the genus Ilex L., in the monogeneric family Aquifoliaceae. We estimate from the regional taxonomic literature that there are at least 669 known Ilex species. Ilex is the second largest dioecious plant genus in the world, after Diospyros L., with 730 accepted species according to Plants of the World Online (POWO) [1]. A recently published phylogeny, based on two nuclear genes, includes 177 Ilex species spread across the geographical range of the genus [2]. This shows that the genus originated in East Asia in the early Eocene and is now near-cosmopolitan in mesic habitats, although most species are found in subtropical East Asia and montane South America. The first high-quality genome for a member of the genus has also recently been published, for I. polyneura [3].

Throughout the range of the genus, Ilex species have been used as sources of beverages and medicines, dyes, timber, and as ornamentals and honey plants. In China, for example, the utilization of Ilex can be traced back to the Song dynasty (year 960-1279), with the Chinese name for Ilex, "dongqing", used in ancient poetry "Méi-Zhōu-Jùn-Pŭ-ZhòngZhì-Băi-Sān-Qiān” (眉州郡固种稚柏三千 in Chinese). They are drunk daily in much of South America, and in every province in southern China, they are part of every Christmas in Europe and North America, and they contribute to human welfare in many other more minor ways. Despite this importance, there has never been a global review of the utilization of the genus. We aim therefore (1) to fill this gap, and (2) to make use of recent advances in the genomics, phylogenetics, and biogeography of the genus $[2,3]$ to propose a program both for the screening of currently unutilized wild species for economic potential and for the genomically informed breeding of those species that are already in 
cultivation. Details of the literature search strategy can be found in the Supplementary File (see Supplementary Materials).

\section{Hollies Utilized as Sources of Beverages}

The scientific literature on Ilex is dominated by phytochemistry and Yao et al. [2] suggest that the diversity and distinctiveness of the defensive chemicals found in members of this genus could have been the innovation that opened new ecological opportunities in the early Eocene, when the crown clade diversified more than 30 million years after the origin of the genus and family. This phytochemistry is also the basis of two of the major uses of Ilex species, as sources of beverages and of medicines. We consider these uses in separate sections here, but all four major types of Ilex tea are seen as healthy beverages by their traditional consumers and are promoted as health drinks to novel consumers in the west (e.g., on www.amazon.com, accessed on 1 June 2021). The constituent species also all have specific traditional medical uses.

Infusions of leaves and/or twigs of Ilex species-hereafter, holly teas-are mainly produced and consumed in China, South America, and the United States. Each region has its own holly tea made from one or more native species of Ilex. The holly tea in China is called 'kudingcha' (bitter spike tea) and is mainly made of leaves of I. latifolia Thunb. and I. kaushue S.Y. Hu (Figure 1a,b), with the latter species most important in terms of market share [4]. The scientific name Ilex kudingcha C.J. Tseng, which is widely used in the Chinese literature, is a synonym of I. kaushue. Confusingly, the name kudingcha is also applied to teas used in a similar way in different regions and by different minorities in southern China, but made from unrelated genera, including Ligustrum L. and Osmanthus Lour. (Oleaceae), Cratoxylum Blume (Hypericaceae), Clerodendrum L. (Verbenaceae), Ehretia P. Browne (Boraginaceae), Photinia Lindl. and Malus Mill. (Rosaceae), Mahonia Nutt. (Berberidaceae), Camellia L. (Theaceae), and Ampelopsis Michx. (Vitaceae) [5-7]. Ligustrum robustum (Roxb.) Blume is widely used in Guizhou, Sichuan, and Yunnan, and is sometimes called small-leaved kudingcha [8]. Additional species of Ilex, including I. cornuta Lindl. \& Paxton and I. pentagona S.K. Chen, Y.X. Feng \& C.F. Liang, are also used in kudingcha in some regions in China [7], and the leaves of other species, including I. asprella Champ. ex Benth. [9] and I. pubescens Hook. \& Arn. [10], are major components of herbal teas sold as health drinks. New ethnobotanical investigations, coupled with molecular identification, among ethnic minorities in Guizhou, Guangxi, Hunan, and Guangdong, could probably be added to this list.

The lack of a unified definition of kudingcha makes it impossible to estimate the annual production and sales of the kudingcha holly species. Kudingcha is still mainly produced in traditional plantations and workshops rather than modern factories, and production methods and quality vary widely. These factors make branding difficult in China and impossible to non-Chinese consumers overseas, limiting what could be a potentially large export market. The distinctive bitterness is unlike other popular teas, but it is an easily acquired taste and could be an advantage in a drink promoted for its health benefits. It does not contain caffeine or other methylxanthines [11], which could also be selling point (Table 1). 


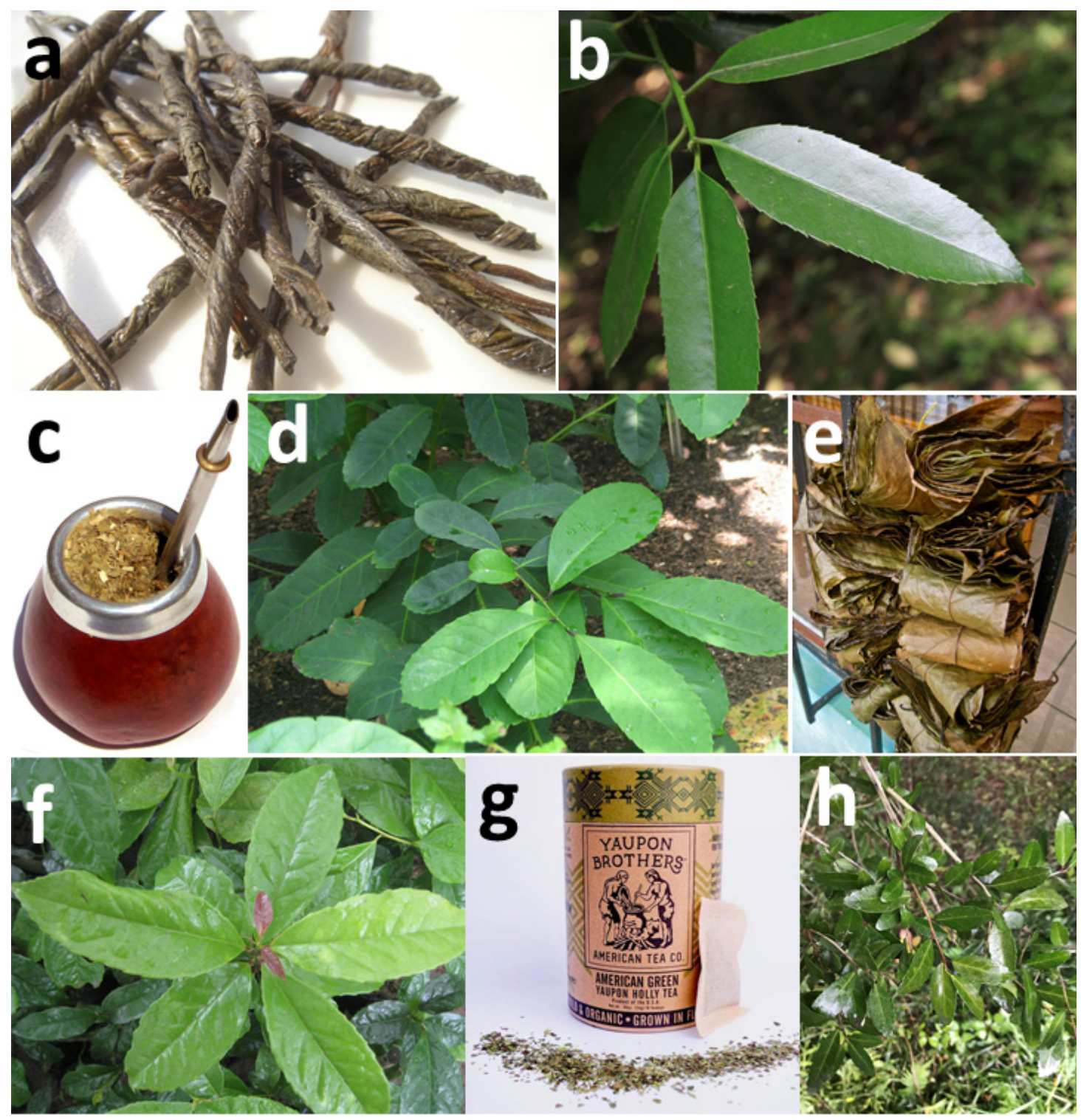

Figure 1. Holly beverages in China-(a) kudingcha and (b) one of its source plants Ilex latifolia; South America-yerba maté (c) and guayusa (e) and their source plants I. paraguariensis (d) and I. guayusa (f); and the United States-yaupon (g) and its source plant I. vomitoria (h). Photographs from Wikimedia Commons by Sjschen (a); Jorge Alfonso Hernández (c); Phyzome (d); Anna Premo (e,f) and Bryon White in the Yaupon Brothers American Tea Co. (g).

Table 1. Xanthine (caffeine, theobromine, and theophylline) contents in source plants of different holly beverages. ND means no detection; NQA means no quantifiable amount. All these contents were calculated based on $1 \mathrm{~g}$ dry weight. Note that several early reports of caffeine content have not been confirmed by subsequent studies with improved techniques and are not included here.

\begin{tabular}{|c|c|c|c|c|c|}
\hline Beverage & Species & $\begin{array}{l}\text { Caffeine Content } \\
(\mathrm{mg} / \mathrm{g})\end{array}$ & $\begin{array}{l}\text { Theobromine } \\
\text { Content (mg/g) }\end{array}$ & $\begin{array}{l}\text { Theophylline } \\
\text { Content (mg/g) }\end{array}$ & Sources \\
\hline \multirow[t]{2}{*}{ kudingcha } & Ilex latifolia & ND & ND & ND & [11] \\
\hline & Ilex kaushue & ND & ND & ND & [11] \\
\hline \multirow[t]{3}{*}{ yerba maté } & Ilex paraguariensis & $11.86 \pm 0.07$ & $0.86 \pm 0.11$ & $0.008 \pm 0.001$ & [11] \\
\hline & Ilex brevicuspis & ND & ND & ND & [12] \\
\hline & Ilex theezans & NQA & ND & NQA & [12] \\
\hline
\end{tabular}


Table 1. Cont.

\begin{tabular}{|c|c|c|c|c|c|}
\hline Beverage & Species & $\begin{array}{c}\text { Caffeine Content } \\
(\mathrm{mg} / \mathrm{g})\end{array}$ & $\begin{array}{l}\text { Theobromine } \\
\text { Content (mg/g) }\end{array}$ & $\begin{array}{l}\text { Theophylline } \\
\text { Content (mg/g) }\end{array}$ & Sources \\
\hline & Ilex microdonta & ND & ND & ND & [13] \\
\hline & Ilex dumosa & NQA & ND & NQA & [12] \\
\hline & Ilex taubertiana & $\widehat{N D}$ & ND & $\widehat{\mathrm{ND}}$ & [14] \\
\hline & Ilex pseudobuxus & NQA & ND & $0.6 \pm 0.2$ & [12] \\
\hline & Ilex integerrima & $\widehat{\mathrm{ND}}$ & ND & ND & [14] \\
\hline & Ilex argentina & ND & NQA & $\mathrm{ND}$ & [12] \\
\hline guayusa & Ilex guayusa & $26.94 \pm 0.88$ & $0.08 \pm 0.02$ & $0.004 \pm 0.001$ & [11] \\
\hline yaupon & Ilex vomitoria & $8.44 \pm 0.31$ & $0.97 \pm 0.14$ & $0.014 \pm 0.002$ & [11] \\
\hline
\end{tabular}

In South America, two types of caffeine-containing holly tea, yerba maté (erva mate in Brazil) and guayusa, are produced. By far the most widely drunk is yerba maté, made of the minced leaves and twigs of I. paraguariensis A.St.-Hil. (Figure 1c,d). Three different beverages are made: chimarrão, terere, and matétea: chimarrão and terere are prepared in a dried gourd, with hot and cold or ice water, respectively, while matétea has an additional roasting step [15]. At least another nine other Ilex species (of the 15 that grow in the same region of subtropical South America) have been used in yerba maté production as substitutes and/or adulterants, including I. argentina Lillo, I. brasiliensis (Spreng.) Loes., I. brevicuspis (Spreng.) Loes., I. dumosa Reissek, I. integerrima Reissek, I. microdonta Reissek, I. pseudobuxus Reissek, I. taubertiana Loes., and I. theezans Mart. Of these, I. dumosa, known as yerba señorita, is now promoted as a legal, caffeine-free alternative to, or admixture with, I. paraguariensis [16,17].

Yerba maté is produced and mainly consumed in Argentina, southern Brazil, Paraguay, and Uruguay, with Argentina and Brazil the major producers and Uruguay a major importer [18]. Global production was estimated at 950,000 tons in 2019. It was originally consumed by the Guaraní and other indigenous peoples, and its use spread more widely in colonial times, but still largely within the native range of the species. Production systems range from harvesting from spontaneous plants in natural forest through traditional polycultures to heavily managed monocultures, using fertilization and herbicides [19,20]. A study in Argentina found a high genetic diversity in plantations, suggesting a considerable potential for breeding programs [21].

Exports are increasing, largely from Argentina and Brazil, with the former exporting 40,000 tons in 2019 and the latter 36,000 tons. Returning Syrian and Lebanese immigrants from Argentina introduced yerba maté to the Middle East, where Syria, the largest overseas market, imported 32,000 tons and Lebanon 800 tons in 2019. Chile, France, and the USA were other major importers outside the native range. In addition to its traditional consumption as a simple infusion, yerba maté is also now available online in a wide range of blended infusions, canned soft drinks, foods, and cosmetics.

The other caffeinated holly beverage in South America is guayusa, made from the leaves of I. guayusa Loes. (Figure 1e,f). Guayusa is produced and consumed in Ecuador, and in adjacent parts of Colombia and northern Peru. There is also an archaeological record from a fifth century tomb in Bautista Saavedra Province in the highlands of Bolivia [22], suggesting possible wider use in the past. The species is only known from cultivation and abandoned settlements, so the native range, if the species exists in the wild, is unknown. Genetic studies using 17 SSR markers revealed a moderately low genetic diversity in the Ecuadorian Amazon [23]. It is widely grown and consumed by the indigenous peoples of the region, including the Kichwas, Shuar, and Achuar, both as a stimulant tea in the morning and for specific medicinal uses [22]. The mestizo and white populations consume it as an additive to spirits, and in other drinks. Production is still dominated by traditional agroforestry systems and, in comparison with yerba maté, the export market is tiny $[23,24]$. However, the mild, unbitter taste makes it potentially attractive as an alternative and it 
is now widely promoted as a health drink in the USA and Europe, including mixed with mint or berries in canned soft drinks.

In the United States, the caffeinated holly beverage, yaupon, is made of crushed leaves and twigs of I. vomitoria Aiton, which is native to the southeast, from Virginia south to central Florida and west to Oklahoma and eastern Texas. Traditionally consumed and traded widely by various Native American groups it became popular with European colonists and substituted for imported tea and coffee during the Civil War [25,26]. In the eighteenth century it was exported to Paris and London and was even cultivated in Britain [26]. However, its use has rapidly declined since, perhaps in part because of its off-putting botanical name, which reflects its historical association with ritualized vomiting in Amerindian 'black drink' rituals rather than any emetic properties. There has been a slow revival recently, but it is still the least consumed of all the major holly teas.

The dried and roasted leaves of another North American species, I. opaca Aiton, sometimes called Appalachian tea, were also reportedly used by Native Americans to brew tea, but this use is poorly documented. The leaves of this species apparently do not contain caffeine [11]. There are also records of teas made from leaves of I. cassine L., I. glabra (L.) A.Gray, and I. verticillata (L.) A.Gray [27] in North America, again poorly documented, and of I. aquifolium L. in the Black Forest in Europe [28].

The contrast between the many species (22) named in this section on beverages and the few that account for more than $99.9 \%$ of all cups drunk suggests a strong selective pressure from consumers. In the Americas, this is clearly primarily selection for caffeine and other stimulants, with all known caffeine-rich species now commercially exploited (Table 1). In China, where Camellia sinensis (L.) Kuntze has dominated this stimulant niche for millennia, selection has been on a wider range of perceived virtues, which probably accounts for the greater diversity of species still exploited.

\section{Hollies Utilized as Sources of Medicines}

The majority of the Ilex literature is concerned with the phytochemistry of the genus and/or potential pharmacological uses. Some of the analytical methods used in the older literature are no longer considered reliable, so we have largely relied on critical reviews and the most recent publications. More than 200 compounds have been identified from the Chinese species I. pubescens alone [10], so the total for all species must be considerably larger than this. Triterpenoids and triterpenoid saponins are the most diverse, along with flavonoids, sterols, polyphenols, and other compounds [10,29]. Most have been isolated from leaves, bark, and roots, the traditional sources of most medicines, but fruits have also yielded new compounds. Most studies have been conducted in China, although there is also a large literature from South America in relation to the chemistry and pharmacology of I. paraguariensis (e.g., Noureddine et al. [30]), and a few studies of other species, including I. brevicuspis [31,32] and I. guayusa [33,34].

In China, written accounts of medicinal hollies extend back more than a millennium and uses for I. chinensis Sims and I. cornuta are recorded in detail in the massive 16th century compendium běn căo gāng mù [29]. These two species and I. rotunda Thunb. are included in the Chinese Pharmacopeia 2015, and these three plus I. pubescens are components of Chinese patent drugs. More than 172 patents for drugs based on Ilex species had been approved up to 15 March 2021 (http:/ / pharmdata.ncmi.cn/pharmpatent/AnalyseSearch. asp? content=7, accessed on 15 March 2021). Other species, such as I. asprella [9] and I. hainanensis Merr. [35], are used as folk medicines. More than 20 Chinese Ilex species have medicinal uses recorded [36]. Some of these species are cultivated for medicinal purposes and others harvested from the wild, or both. The quantities used can be huge, e.g., more than 10,000 tons a year for I. asprella [9].

The applications of Ilex species in traditional Chinese medicine are summarized by Yi et al. [29]. Reported pharmacological activities of potential medical use include protection of the cardiovascular system and regulation of lipid metabolism, anti-tumor activity, antioxidant and anti-inflammatory activity, anti-diabetic and anti-obesity activity, and 
anti-microbial activity, among others. A similar range of health benefits has been reported for I. paraguariensis in South America [30]. New compounds and new activities are regularly added to this already long list (e.g., Shao et al. [37]). Modern pharmacological research methods are being increasingly applied to studies of Ilex species, but controlled clinical trials are still rare and the active components and their mechanism of action are usually unclear [10]. Moreover, only a fraction of Chinese species has been investigated and even fewer outside China, where uses in folk medicine were also widespread (e.g., I. dipyrena Wall. in India and Pakistan [38]; I. aquifolium in Europe [28,39]).

\section{Hollies Utilized as Ornamental Plants}

Many hollies are rather inconspicuous plants in their natural communities, with small pale flowers, small red or black fruits, and unremarkable leaves. However, some attract attention, even in the wild, with their glossy evergreen leaves or persistent massed red fruits. In China, Ilex species have been mentioned in classical poetry since at least the Song dynasty (year 960-1279) and many species have been cultivated as ornamentals, including I. cornuta, I. chinensis, I. integra Thunb., and I. crenata Thunb., all evergreen shrubs with red fruits [40].

In much of Europe, I. aquifolium is both the only holly species and, because of its glossy evergreen foliage and bright red fruits, one of the most conspicuous woody plants, particularly in winter. As a result, it has accumulated legendary attributes and symbolic roles linked with Christian and pre-Christian beliefs and has been utilized in winter festivals, particularly Christmas $[28,41]$. To Christians, the thorny foliage symbolizes Christ's crown of thorns, the berries are like drops of his blood, and the evergreen habit is a symbol of life after death. Kristtorn (Christ's thorn) is the name for holly in Danish and Norwegian, and Christdorn is sometimes used in German.

In North America, I. verticillata and I. decidua Walter are grown to supply cut, leafless branches with bright red fruits for winter decorations. These two species are increasingly grown commercially for the same purpose in eastern China, along with a native species, $I$. polyneura (Hand.-Mazz.) S.Y. Hu, from a different clade but with a similar phenotype [2].

Distinct horticultural cultivars have been developed for several of the ornamental species and many artificial hybrids now exist, such as I. $\mathrm{x}$ altaclerensis, a hybrid between I. aquifolium and I. perado Aiton which arose in cultivation more than 200 years ago and now has numerous cultivars, mostly with variegated leaves. Some cultivars are hybrids between distantly related species, such as such as Ilex x koehneana 'Chestnut Leaf', which is a hybrid between I. aquifolium (C5 clade in the phylogeny in Figure 2) and I. latifolia (C1 clade), Ilex 'Sparkleberry', which is a hybrid between I. serrata (E6 clade) and I. verticillata (E8 clade), and Ilex 'Lydia Morris', which is a hybrid between I. cornuta (C4 clade) and I. pernyi (C6 clade). A total of 115 holly cultivars have been registered with the Holly Society of America since 1994, most of which are hybrids of I. opaca, I. aquifolium, I. crenata, I. verticillata, I. serrata Thunb., I. cornuta, I. glabra, I. pernyi Franch., or I. cassine (http:/ /hollysocam.org/registrations.htm, accessed on 15 March 2021). In China, seven cultivars (of unspecified parentage) were approved by the National Forestry and Grassland Administration between 2000 and 2021 (http:/ / www.forestry.gov.cn/main/3457/index.html, accessed on 15 March 2021). The numerous (>500) cultivars of I. crenata are particularly popular in East Asia (https: / www.seattlejapanesegarden.org/blog/2017/12/13/theunobtrusive-beauty-of-japanese-holly, accessed on 15 March 2021). 


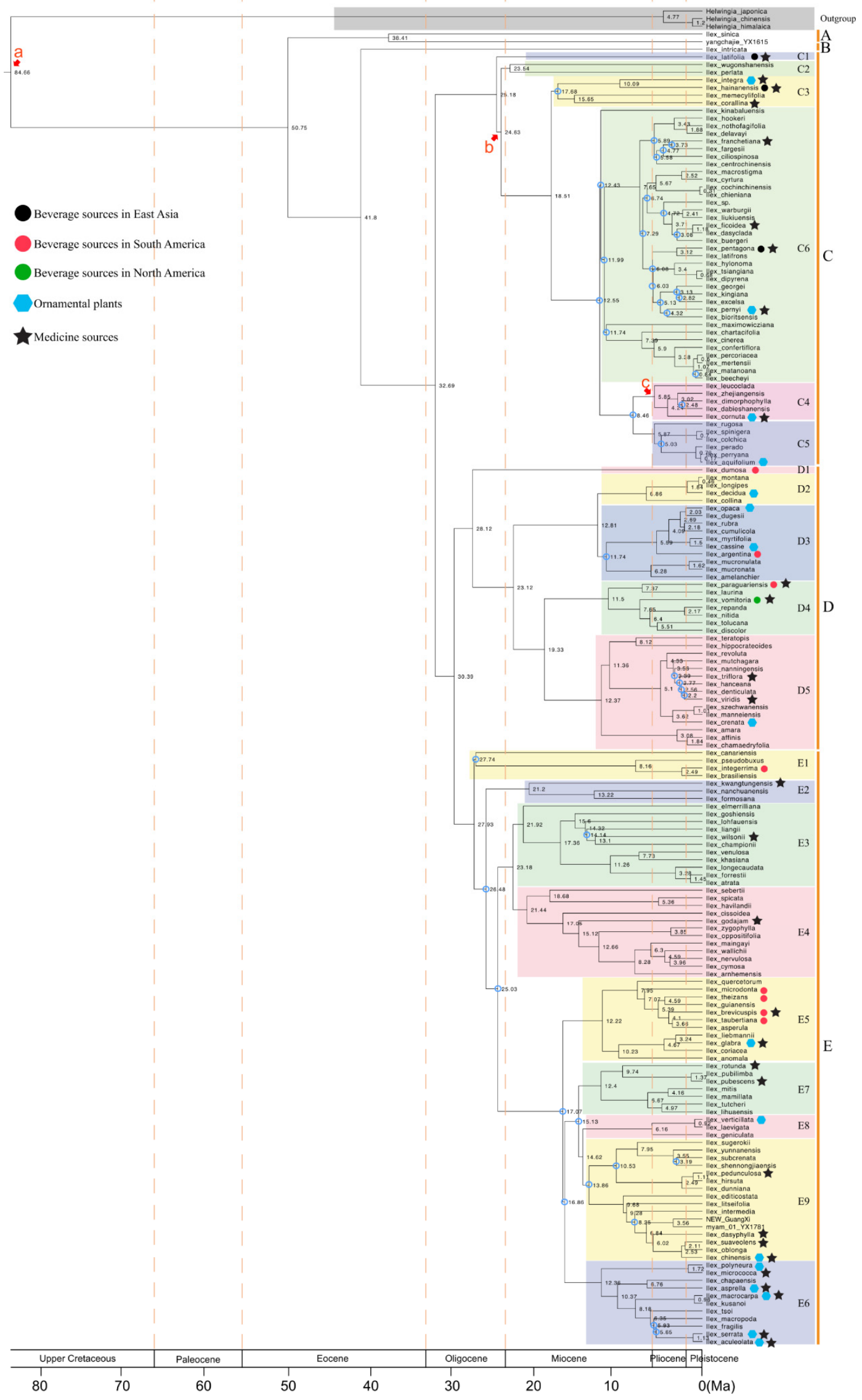

Figure 2. Ilex species with different uses mapped onto the phylogeny, based on Figure 1 in Yao et al. [2]. 
This figure is a chronogram of 177 Ilex species with three macrofossil constraints and three Helwingiaceae species as outgroups, estimated in BEAST2, A-E indicated the phylogenetic clades. Positions of the fossil constraints are indicated with red arrows and letters $(\mathrm{A}-\mathrm{C})$. Median ages are presented near nodes as million years (Ma). Nodes with posterior probability lower than 0.80 are labeled by empty blue circles. Black, red and green circles next to species name indicate that it is used as a beverage source in East Asia, South America or North America, respectively. Blue hexagons and black stars indicate species that are used as ornamental plants or medicine sources, respectively.

\section{Hollies Utilized as Honey Plants}

Ilex species produce large displays of small flowers with accessible pollen and nectar, both of which are attractive to bees, particularly social bees. A comparison among nine Ilex species in Hong Kong found a large variation between species in nectar production, sugar concentration, and sugar composition, but the rate of Apis cerana Fabricius visits per flower was predicted only by the estimated total number of flowers per plant [42]. Ilex species are important sources for commercial honey production from honeybees in China [43], Nepal [44], Ethiopia [45], Kenya [46], Surinam [47], the USA [48,49], and no doubt other places. In the USA, specialty holly honeys derived from bees feeding on I. glabra, I. coriacea (Pursh) Chapm., or I. vomitoria are available on-line.

\section{Other Uses}

\subsection{Timber}

In a global comparison of Ilex wood anatomy covering 78 species, Baas [50] found a major climatic influence, with temperate and subtropical species having conspicuous growth rings and numerous narrow, relatively short vessels, tropical lowland species having scanty, wide, long vessels and no or inconspicuous growth rings, and tropical montane species similar to temperate species, except for the absence of growth rings. This anatomical diversity must influence timber properties, but the genus is not important enough as a timber source to merit a such a comparative study. Wood densities of the 36 Ilex species listed in the Tree Functional Attributes and Ecological Database ranged from $0.44 \mathrm{~g} / \mathrm{cm}^{3}$ in I. arnhemensis Loes., from tropical lowland Australia, to 0.78 in I. aquifolium, from temperate Europe, and 0.88 in 'Ilex sp. 2', from Indonesia with no location (http: / / db.worldagroforestry.org//wd/species/Ilex, accessed on 15 March 2021).

The larger Ilex species are probably used everywhere as minor timbers, but rarely as a first choice (e.g., Shupe et al. [51]). I. mitis (L.) Radlk., the only species in sub-Saharan Africa, has been used in a wide variety of light construction and the manufacture of small items [52], and similar uses are mentioned for other species in Papua New Guinea [53], Southeast Asia [54], China [36], Brazil [55], and elsewhere. In Europe and North America, I. aquifolium and I. opaca provide dense, fine-grained, exceptionally pale timbers which are used for a variety of ornamental and decorative purposes. I. aquifolium has been extensively used for inlaying and turnery, and was also often stained various colors [28].

\subsection{Minor Uses}

Natural brown and blue-black dyes have been extracted from the leaves [56-59] and fruits [60] of Ilex species. The bark of I. aquifolium was a traditional source of birdlime, spread on twigs to catch small birds, and the evergreen branches were cut for feeding cattle, sheep, and deer in winter [37].

\section{Future Prospects for Utilization of Ilex Species}

This review names 38 species of Ilex which have been utilized as beverages, medicines, timbers, and/or dyes, but this is only 6\% of the 669 known species in the genus. In most cases, it is a wild type that is utilized, although this may have been selected from a greater diversity of wild phenotypes and some of these selections are cultivated in huge numbers. Distinct domesticated cultivars are found only in ornamental species. We have 
undoubtedly missed accounts of Ilex utilization in the literature in languages other than English, Chinese, Portuguese, and Spanish, and this literature has certainly missed local and/or minor uses of additional species. Some of the currently unutilized species may have been tried and rejected as substitutes for utilized species, but much of the diversity in the genus is in rare species and in remote, or until recently remote, areas of southwest China and the Andes [2,3], and most of these species have probably never been evaluated for potential uses.

The recently published phylogeny, including 177 Ilex species spread across the geographical range of the genus [2], can facilitate screening of additional species, both by aiding molecular identification and by predicting which clades are most likely to have desired characteristics. Ilex species can be difficult to identify from morphology, particularly when sterile, and identification is usually impossible for the dried material sold for use as teas and medicines. The internal transcribed spacer (ITS) nuclear marker used in the construction of the phylogeny is also ideal for molecular identification of these materials because of its small size, high copy number, and the variation between closely related species [61]. Ethnobotanical investigations coupled with molecular identification would be particularly valuable in southwest China and the eastern Himalaya region, where both Ilex and ethnic diversity are high, but are also likely to be useful elsewhere to distinguish dried leaf material from other taxa.

The broad categories of uses of Ilex species are scattered across the phylogeny (Figure 2), but the two sources of caffeinated teas with sequence data, I. paraguariensis and I. vomitoria, belong to the same clade (D4), suggesting that other species in this clade should be screened for this useful trait. In the same way, the phylogeny can potentially be used to predict species with shared medicinal, ornamental, and timber properties. In contrast, the lack of clustering of the Ilex species used for tea in China is perhaps not surprising in view of the non-specific health benefits attributed to these teas and the many unrelated genera also used for the same purpose.

The availability of a complete genome of Ilex polyneura (about $727.10 \mathrm{Mb}$ in length) [3] can potentially facilitate breeding programs for Ilex species which are already of economic importance. The authors conducted a population genomics study across the elevation range of this species, using this genome as a reference, and found evidence for significant local adaptation, suggesting that it will be worthwhile to screen multiple wild populations of widespread species for useful traits. The sizes and long generation times of woody species means that breeding for trait enhancement is slow and expensive, but genomic data can accelerate this (e.g., Lebedev et al. [62]; O'Connor et al. [63]). The identification of markers linked to useful traits is the most common application of whole genomes in crop breeding and could potentially be used to accelerate selection for any useful trait. With a large enough reference population of individuals with known phenotypes and genotypes (the training population), it is possible to develop models that use a high density of genomewide markers to predict useful traits at the seedling stage, before the adult phenotypes can be assessed, saving both time and space. Finally, the positioning of holly teas as natural health foods probably precludes the use of both conventional genetic modification and precision genome editing with CRISPR/Cas systems to enhance their properties, but this consideration does not apply to ornamental hollies or to the production of particular pharmaceutical compounds.

Supplementary Materials: The following supporting information can be downloaded at: https: / / www.mdpi.com/article/10.3390/f13010094/s1, Supplementary File is the detail of the literature search strategy.

Author Contributions: Conceptualization, X.Y. and R.T.C.; investigation, X.Y. and F.Z.; resources, X.Y., F.Z. and R.T.C.; writing-original draft preparation, X.Y.; writing—review and editing, X.Y., F.Z. and R.T.C.; visualization, X.Y.; supervision, R.T.C.; funding acquisition, X.Y. All authors have read and agreed to the published version of the manuscript. 
Funding: This research was funded by grants from the CAS "Light of West China" Program (Y9XB071B01), the Yunnan Fundamental Research Projects (grant NO. 202001AT070120), and the National Natural Science Foundation of China (41901067) to X.Y.

Data Availability Statement: Not applicable.

Acknowledgments: We wish to thank Zhengwei Wang for useful discussions about honey plants.

Conflicts of Interest: The authors declare no conflict of interest.

\section{References}

1. POWO. Plants of the World Online. Available online: http:/ /www.plantsoftheworldonline.org/ (accessed on 4 November 2021)

2. Yao, X.; Song, Y.; Yang, J.B.; Tan, Y.H.; Corlett, R.T. Phylogeny and biogeography of the hollies (Ilex L., Aquifoliaceae). J. Syst. Evol. 2021, 59, 73-82. [CrossRef]

3. Yao, X.; Lu, Z.; Song, Y.; Hu, X.; Corlett, R.T. A chromosome-scale genome assembly for the holly (Ilex polyneura) provides insights into genomic adaptations to elevation in Southwest China. Hortic. Res. 2021. accepted.

4. $\quad$ Li, L.; Xu, L.J.; Ma, G.Z.; Dong, Y.M.; Peng, Y.; Xiao, P.G. The large-leaved kudingcha (Ilex latifolia Thunb and Ilex kudingcha CJ Tseng): A traditional Chinese tea with plentiful secondary metabolites and potential biological activities. J. Nat. Med. 2013, 67, 425-437. [CrossRef] [PubMed]

5. Chen, W.; Li, X.; Peng, P.; Peng, J.; Wang, L. Kudingcha resources and rural kudingcha in Sichuan. Fujianchaye 2004, 1, 9-10.

6. Zhang, D.; Yan, D. Development prospect and domestication cultivation of kudingcha (Ilex pentagona) in mountainous areas of Guizhou province. J. Guizhou Agric. Sci. 2004, 32, 85-87.

7. Gu, J.; Peng, Y.; Xu, L.; Xiao, W.; Chen, Z.; Xiao, P. Sources investigation and characters identification of kudingcha production. J. Chin. Med. Mater. 2011, 34, 196-199.

8. Liu, B.; Ma, R.; Zhang, J.; Sun, P.; Yi, R.; Zhao, X. Preventive effect of small-leaved kuding tea (Ligustrum robustum (Roxb.) Bl.) polyphenols on D-galactose-induced oxidative stress and aging in mice. Evid.-Based Complement. Altern. Med. 2019, 2019, 3152324. [CrossRef] [PubMed]

9. Chen, W.; Zhou, L.; Qiao, Y.; Qi, J.; Fu, G.; Xia, X. Quality evaluation of Ilex asprella based on simultaneous determination of five bioactive components, chlorogenic acid, luteoloside, quercitrin, quercetin, and kaempferol, using UPLC-Q-TOF MS study. J. AOAC Int. 2019, 102, 1414-1422. [CrossRef]

10. Jiang, S.; Cui, H.; Wu, P.; Liu, Z.; Zhao, Z. Botany, traditional uses, phytochemistry, pharmacology and toxicology of Ilex pubescens Hook et Arn. J. Ethnopharmacol. 2019, 245, 112147. [CrossRef]

11. Negrin, A.; Long, C.; Motley, T.J.; Kennelly, E.J. LC-MS metabolomics and chemotaxonomy of caffeine-containing holly (Ilex) species and related taxa in the Aquifoliaceae. J. Agric. Food Chem. 2019, 67, 5687-5699. [CrossRef]

12. Filip, R.; Lopez, P.; Coussio, J.; Ferraro, G. Mate substitutes or adulterants: Study of xanthine content. Phytother. Res. 1998, 12, 129-131. [CrossRef]

13. Reginatto, F.H.; Athayde, M.L.; Gosmann, G.; Schenkel, E.P. Methylxanthines accumulation in Ilex species-caffeine and theobromine in erva-mate (Ilex paraguariensis) and other Ilex species. J. Braz. Chem. Soc. 1999, 10, 443-446. [CrossRef]

14. Seyed, M.A.R. Determinación de Arbutina en las Especies de Ilex. Ph.D. Thesis, Universidad de Belgrano, Buenos Aires, Argentina, 2012.

15. Mesquita, M.; Santos, E.; Kassuya, C.A.; Salvador, M.J. Chimarrão, terere and mate-tea in legitimate technology modes of preparation and consume: A comparative study of chemical composition, antioxidant, anti-inflammatory and anti-anxiety properties of the mostly consumed beverages of Ilex paraguariensis St. Hil. J. Ethnopharmacol. 2021, 279, 114401. [PubMed]

16. Gottlieb, A.M.; Poggio, L. Quantitative and qualitative genomic characterization of cultivated Ilex L. species. Plant Genet. Resour. 2015, 13, 142-152. [CrossRef]

17. Maiocchi, M.G.; Gorrales, L.; Cardoso-Schiavi, P.; Serrano, N.; Petenatti, E.M.; Marchevsky, E.J.; del Vitto, L.A. Nutritional parameters of "mate cocido" with milk prepared from two species of Ilex and their commercial mixture for school age population. Rev. Fac. Cienc. Agrar. 2018, 50, 203-216.

18. FAOSTAT. Available online: https:/ / www.fao.org/faostat/en/\#search/Mat\%C3\%A9 (accessed on 4 November 2021).

19. Croge, C.P.; Cuquel, F.L.; Pintro, P.T.M. Yerba mate: Cultivation systems, processing and chemical composition. A review. Sci. Agric. 2021, 78, e20190259. [CrossRef]

20. Magri, E.; Gugelmin, E.K.; Grabarski, F.A.P.; Barbosa, J.Z.; Auler, A.C.; Wendling, I.; Prior, S.A.; Valduga, A.T.; Motta, A.C.V. Manganese hyperaccumulation capacity of Ilex paraguariensis A. St. Hil. and occurrence of interveinal chlorosis induced by transient toxicity. Ecotoxicology 2020, 203, 111010. [CrossRef] [PubMed]

21. Paiva, D.I.; Cascales, J.; Rosetti, M.E.N.; Scherer, R.A.; Gauchat, M.E.; Gottlieb, A. Unraveling the genetic complexity of a cultivated breeding population of "yerba mate"(Ilex paraguariensis St. Hil.). An. Acad. Bras. Cienc. 2020, 92, e20190113. [CrossRef]

22. Dueñas, J.F.; Jarrett, C.; Cummins, I.; Logan-Hines, E. Amazonian guayusa (Ilex guayusa Loes.): A historical and ethnobotanical overview. Econ. Bot. 2016, 70, 85-91. [CrossRef]

23. Erazo-Garcia, M.P.; Guadalupe, J.J.; Rowntree, J.K.; Borja-Serrano, P.; de los Monteros-Silva, N.E.; Torres, M.D.L. Assessing the genetic diversity of Ilex guayusa Loes., a medicinal plant from the Ecuadorian Amazon. Diversity 2021, 13, 182. [CrossRef] 
24. Wise, G.; Negrin, A. A critical review of the composition and history of safe use of guayusa: A stimulant and antioxidant novel food. Crit. Rev. Food Sci. Nutr. 2020, 60, 2393-2404. [CrossRef] [PubMed]

25. Wainwright, A.E.; Putz, F.E. A misleading name reduces marketability of a healthful and stimulating natural product: A comparative taste test of infusions of a native Florida holly (Ilex vomitoria) and yerba mate (I. paraguariensis). Econ. Bot. 2014, 68, 350-354. [CrossRef]

26. Folch, C. Ceremony, medicine, caffeinated Tea: Unearthing the forgotten faces of the North American stimulant yaupon (Ilex vomitoria). Comp. Stud. Soc. Hist. 2021, 63, 464-498. [CrossRef]

27. Yanovsky, E. Food Plants of the North American Indians; United States Department of Agriculture Miscellaneous Publications No. 237; United States Department of Agriculture: Washington, DC, USA, 1936.

28. Grieve, M. A Modern Herbal; Harcourt, Brace \& Company: New York, NY, USA, 1931.

29. Yi, F.; Zhao, X.; Peng, Y.; Xiao, P. Genus Ilex L.: Phytochemistry, ethnopharmacology, and pharmacology. Chin. Herb. Med. 2016, 8 , 209-230. [CrossRef]

30. Noureddine, T.; El Husseini, Z.; Nehme, A.; Massih, R.A. Antibacterial activity of Ilex paraguariensis (Yerba Mate) against Gram-positive and Gram-negative bacteria. J. Infect. Dev. Ctries. 2018, 12, 712-719. [CrossRef] [PubMed]

31. Mallmann, A.P.; dos Santos, C.V.; da Silva, T.L.; Bandeira, D.M.; Lakoski, L.V.; Rosset, J.; Conceição, L.H.S.M.; Pinto, F.G.S. Yield, phytochemical characterization and evaluation of antibacterial and antioxidante activity of Ilex brevicuspis (Aquifoliaceae) Reissek extracts against Salmonella spp. serotypes of poultry origen. Braz. J. Dev. 2021, 7, 29143-29158. [CrossRef]

32. Mallmann, A.P.; dos Santos, C.V.; Toledo, A.G.; Lakoski, L.V.; Bandeira, D.M.; Corrêa, J.M.; Pinto, F.G.S. Determination of the phytochemical profile and evaluation of biological activities of leaf extracts of Ilex brevicuspis Reissek. (Aquifoliaceae). Res. Soc. Dev. 2021, 10, e10210313154. [CrossRef]

33. García-Ruiz, A.; Baenas, N.; Benítez-González, A.M.; Stinco, C.M.; Meléndez-Martínez, A.J.; Moreno, D.A.; Ruales, J. Guayusa (Ilex guayusa L.) new tea: Phenolic and carotenoid composition and antioxidant capacity. J. Sci. Food Agric. 2017, 97, 3929-3936 [CrossRef] [PubMed]

34. Chóez-Guaranda, I.; Viteri-Espinoza, R.; Barragán-Lucas, A.; Quijano-Avilés, M.; Manzano, P. Effect of solvent-solvent partition on antioxidant activity and GC-MS profile of Ilex guayusa Loes. leaves extract and fractions. Nat. Prod. Res. 2021. [CrossRef]

35. Zhang, Y.Q.; Yang, H.; Sun, W.D.; Wang, J.; Zhang, B.Y.; Shen, Y.J.; Yin, M.Q.; Liu, Y.X.; Liu, C.; Sun, Y. Ethanol extract of Ilex hainanensis Merr. exhibits anti-melanoma activity by induction of G 1/S cell-cycle arrest and apoptosis. Chin. J. Integr. Med. 2018, 24, 47-55. [CrossRef]

36. Zhuang, H.; Wang, C.; Wang, Y.; Jin, T.; Huang, R.; Lin, Z.; Wang, Y. Native useful vascular plants of China: A checklist and use patterns. Plant Divers. 2021, 43, 134-141. [CrossRef] [PubMed]

37. Shao, S.Y.; Li, R.F.; Sun, H.; Li, S. New triterpenoid saponins from the leaves of Ilex chinensis and their hepatoprotective activity Chin. J. Nat. Med. 2021, 19, 376-384. [CrossRef]

38. Ali, A.; Khalil, A.A.; Khuda, F.; Nazir, N.; Ullah, R.; Bari, A.; Haider, A.; Jamal, S.B.; Ahmad, S.; Khan, Z.; et al. Phytochemical and biological screening of leaf, bark and fruit extracts from Ilex dipyrena Wall. Life 2021, 11, 837. [CrossRef] [PubMed]

39. Palu, D.; Bighelli, A.; Casanova, J.; Paoli, M. Identification and quantitation of ursolic and oleanolic acids in Ilex aquifolium L. leaf extracts using 13C and 1H-NMR spectroscopy. Molecules 2019, 24, 4413. [CrossRef] [PubMed]

40. Qin, X. Resources investigation of indigenous plants in Nanchang and their application in urban landscape. In Proceedings of the 3rd International Conference on Civil, Architecture and Urban Engineering, Xiamen, China, 30 June 2021.

41. Peterken, G.F.; Lloyd, P.S. Ilex aquifolium L. J. Ecol. 1967, 55, 841-858. [CrossRef]

42. Tsang, A.C.W.; Corlett, R.T. Reproductive biology of the Ilex species (Aquifoliaceae) in Hong Kong, China. Can. J. Bot. 2005, 83, 1645-1654. [CrossRef]

43. Wu, Y.; Yang, Y.; Liu, M.; Wang, B.; Li, M.; Chen, Y. Molecular tracing of the origin of six different plant species in bee honey using real-time PCR. J. AOAC Int. 2019, 100, 744-752. [CrossRef] [PubMed]

44. Bista, S.; Shivakoti, G.P. Honeybee flora at Kabre, Dolakha District. Nep. Agric. Res. J. 2000, 4, 18-25. [CrossRef]

45. Bareke, T.; Addi, A. Bee flora diversity in different vegetation communities of Gsha-Sayilem forest in Kaffa Zone, south-western Ethiopia. Plants Environ. 2000, 2, 138-148. [CrossRef]

46. Orwa, C.; Mutua, A.; Kindt, R.; Simons, A.; Jamnadass, R.H. Agroforestry Database 4: A Tree Reference and Selection Guide; World Agroforestry Centre: Nairobi, Kenya, 2010.

47. Kerkvliet, J.D.; Beerlink, J.G. Pollen analysis of honeys from the coastal plain of Surinam. J. Apic. Res. 1991, 30, 25-31. [CrossRef]

48. Lieux, M.H. Minor honeybee plants of Louisiana indicated by pollen analysis. Econ. Bot. 1978, 32, 418-432. [CrossRef]

49. Grelen, H.E. Ilex opaca. In Silvics of North America: 2. Hardwoods. Agriculture Handbook 654; Burns, R.M., Honkala, B.H., Eds.; University of Michigan Library: Ann Arbor, MI, USA, 1990; pp. 379-385.

50. Baas, P. The wood anatomical range in Ilex (Aquifoliaceae) and its ecological and phylogenetic significance. Blumea 1973, 21, 193-260.

51. Shupe, T.F.; Aguilar, F.X.; Vlosky, R.P.; Belisle, M.; Chavez, A. Wood properties of selected lesser-used Honduran wood species. J. Trop. For. Sci. 2005, 17, 438-446.

52. Maroyi, A. Ilex mitis (L.) Radlk. In PROTA (Plant Resources of Tropical Africa/Resources Végétales de l'Afrique Tropicale); Lemmens, R.H.M.J., Louppe, D., Oteng-Amoako, A.A., Eds.; Foundation PROTA: Wageningen, The Netherlands, 2012. 
53. Conn, B.J.; Damas, K.Q. Guide to Trees of Papua New Guinea. Available online: http:/ / www.pngplants.org/PNGtrees (accessed on 10 April 2021).

54. Wiselius, S.I. Ilex L. In Plant Resources of South-East Asia No. 5(3): Timber Trees; Lesser-Known, Timbers; Sosef, M.S.M., Hong, L.T., Prawirohatmodjo, S., Eds.; PROSEA Foundation: Bogor, Indonesia, 1998.

55. Groppo, M. Neotropical Aquifoliaceae. In Neotropikey: Neotropical Flowering Plants; Milliken, W., Klitgaard, B., Baracat, A., Eds.; Royal Botanic Gardens, Kew: London, UK, 2009.

56. Sensei, K.N. Dyeing and painting using plant pigments. Curtis's Bot. Mag. 1999, 16, 134-136. [CrossRef]

57. Zhu, L. Study on the extraction of natural dye from holly and its dyeing on silk fabric. Text. Aux. 2016, 33, 51-53.

58. Giacomini, F.; Menegazzo, M.A.B.; dos Santos, J.C.O.; Arroyo, P.A.; de Barros, M.A.S.D. Ecofriendly dyeing of silk with extract of yerba mate (Ilex paraguariensis). Text. Res. J. 2017, 87, 829-837. [CrossRef]

59. Vila, N.T.; Ferreira, A.; da Silva, M.G.; Fernandes, M.; Fiori, S. Surface modification of silk by (DBD) dielectric barrier discharge treatment for dyeing with natural dye yerba mate (Ilex paraguariensis). Procedia Eng. 2017, 200, 170-177. [CrossRef]

60. Hamel, P.B.; Chiltoskey, M.U. Cherokee Plants and Their Uses-A 400 Year History; Herald Publishing Co. Inc.: Sylva, NC, USA, 1975.

61. Manen, J.F.; Boulter, M.C.; Naciri-Graven, Y. The complex history of the genus Ilex L. (Aquifoliaceae): Evidence from the comparison of plastid and nuclear DNA sequences and from fossil data. Plant Syst. Evol. 2002, 235, 79-98. [CrossRef]

62. Lebedev, V.G.; Lebedeva, T.N.; Chernodubov, A.I.; Shestibratov, K.A. Genomic selection for forest tree improvement: Methods, achievements and perspectives. Forests 2020, 11, 1190. [CrossRef]

63. O'Connor, K.M.; Hayes, B.J.; Hardner, C.M.; Alam, M.; Henry, R.J.; Topp, B.L. Genomic selection and genetic gain for nut yield in an Australian Macadamia breeding population. BMC Genom. 2021, 22, 370. [CrossRef] [PubMed] 